\title{
Detection of Toxoplasma gondii IgM and Cytomegalovirus IgM antibodies among blood donors in Mosul
}

\author{
Karam A. Al-Dabbagh \\ Department of Pharmacology, College of Pharmacy, University of Mosul, Iraq

$\frac{\text { Received } \quad \text { Accepted }}{2.9 .2010 \quad 31.10 .2010}$

\section{ABSTRACT}

Background: Toxoplasmosis is an infection caused by the protozoan parasite Toxoplasma gondii. This parasite can be transmitted via blood transfusion. Cytomegalovirus (CMV) is a herpes virus that can cause many complications and mostly transfer via blood transfusion. The aim of this study was to evaluate the percentage of risk of infections that could occur due to blood transfusion.

Subjects and methods: Ninety blood donor samples were randomly obtained from central blood bank of Mosul city and investigated for IgM of toxoplasmosis and CMV by the serological method ELISA, IgM.

Results: ELISA test for Toxoplasma gondii IgM test showed 3\% seropositive and for CMV showed $10 \%$ seropositive.

Conclusion: The results indicate a risk of infection with toxoplasmosis and CMV via blood transfusion.

Keywords: Toxoplasma gondii, Cytomegalovirus, blood donors, IgM,.

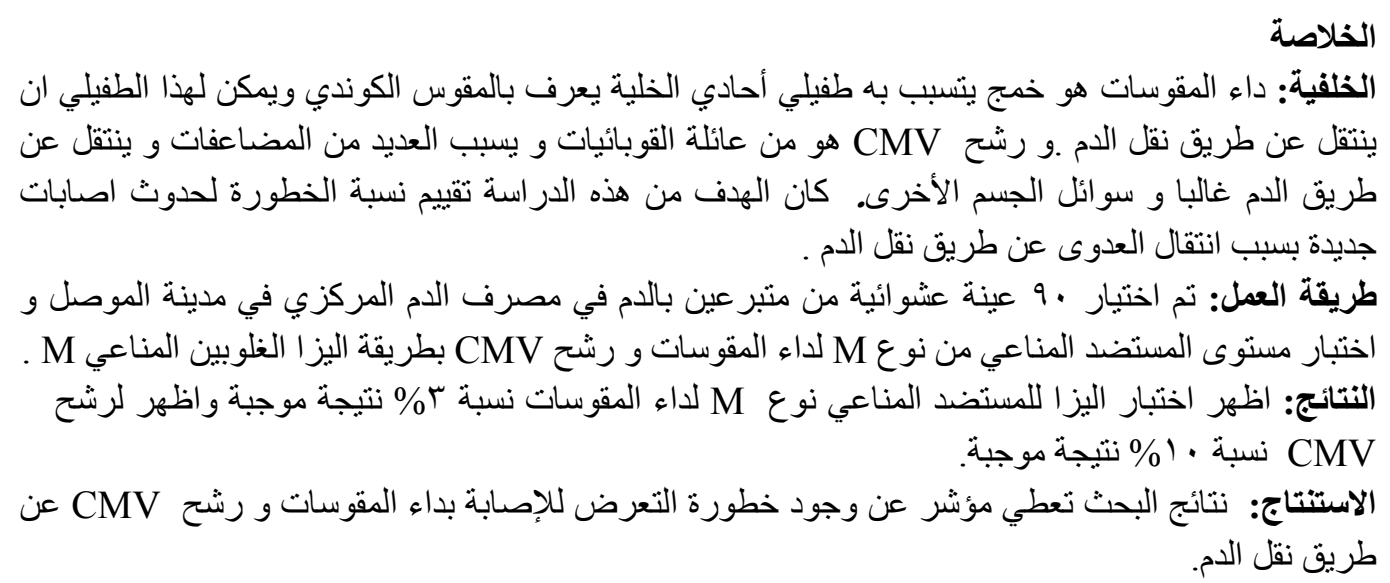

$\prod_{\text {protozoan }}^{\text {oxoplasma }} \begin{gathered}\text { gondii is a coccidian } \\ \text { of }\end{gathered}$ distribution ${ }^{1}$. Researches showed that up to one-third of world's population are infected with toxoplasma gondi ${ }^{1,2}$. Most infections in immune competent individuals are asymptomatic and in some of infected individuals will have one or more of the following symptoms: cervical lymphadenopathy or ocular disease occur in up to $10 \%$ of infected individuals ${ }^{2}$. Fever, a vague ill feeling and sometimes sore throat, blurred vision, and eye pain ${ }^{3}$. Severe 
infection usually develops only in fetuses, which results in congenital toxoplasmosis ${ }^{2,5}$, and in immune compromised patients ${ }^{4}$, which could results in CNS disease as encephalopathy or brain abscess ${ }^{2,6}$.

The mode of transmission of Toxoplasma gondii to human can happen by ingestion of food or water that is contaminated with oocyst shed by cats; also by eating of undercooked or raw meat containing tissue cyst ${ }^{2,6,7}$ or by transplantation and blood transfusion ${ }^{8-11}$.

Since Toxoplasma gondii organisms retain their viability after suspension in citrated blood and storage at $5{ }^{\circ} \mathrm{C}$ for up to 50 days ${ }^{12}$ and since Toxoplasma gondii have been recovered from the buffy coat of patients with toxoplasmosis ${ }^{13}$, it appears likely that toxoplasmosis could be acquired in this fashion, particularly if large concentrations of leukocytes are given from donors who, themselves, are likely to be infected with Toxoplasma gondii ${ }^{12}$.

Human Cytomegalovirus (CMV) is a herpes virus which is globally distributed in human population. Although rarely pathogenic in immunocompetent individuals, the virus possess a significant health threat to immunocompromised individuals and is a significant cause of morbidity and mortality especially in organ allograft and bone marrow transplant patients $^{14,15}$.

Traditionally, congenital CMV disease is known to be the most serious, but prenatal and postnatal acquired infections are also an important cause of morbidity in infants. Humans are believed to be the only reservoir for human $\mathrm{CMV}$, and natural transmission occurs by direct or indirect, close or intimate person-toperson contact. Sources of virus include oropharyngeal secretions, urine, cervical and vaginal excretions, semen, breast milk, tears, feces, and blood $^{16,17}$.

CMV is intracellular virus could be localized in leukocytes and detected by monoclonal antibodies or genetic probes; $\mathrm{CMV}$ is concentrated in neutrophil fraction of the buffy coat, rather in the mononuclear fraction ${ }^{17}$. The host immune response presumably maintains CMV usually remains in a latent state in seropositive individuals and reactivation is more frequent in immune compromised patients than in normal hosts, although usually reactivated infections may be less severe and virulent than primary infections ${ }^{3}$.

Many studies evaluated the risks associated with blood transfusion were conducted in Saudi Arabia, Turkey, Mexico, USA, Thailand, Nigeria and Iraq as well ${ }^{25-35}$, yet this study represent one of the first trails in Mosul city.This study aimed to determine the risk of toxoplasmosis and CMV transmission due to blood donation process.

\section{Materials and methods}

The samples were randomly collected as 30 samples every 2 months in three different periods between December 2007 and May 2008, (total 90 samples) from central blood bank in Mosul city. All samples were taken from male donors (majority of donors were male) 
aged between 20 to 62 years (mean \pm SD: $33.3 \pm 8.73$ years); The donors were apparently healthy.

The samples were tested for HIV and Hepatitis B and C in the bank laboratory. Blood is neglected and destroyed for positive result of HIV and Hepatitis. The samples were taken after exclusion the HIV and Hepatitis and analyzed for anti Toxoplasma gondii IgM antibodies and CMV IgM antibodies by using Toxoplasma gondii IgM enzyme linked immunosorbent assay ELISA method ${ }^{18-21}$ ( Biocheck $^{-1}$ inc. Canada) and CMV IgM enzyme linked immunosorbent assay ELISA method $^{22-24}$ ( Biocheck inc. Canada).

The ELISA test was done by serum dilution 1:40, enzyme conjugate addition, TMB reagent then stop solution is added, read at $450 \mathrm{~nm}$ in ELIZA reader for both Toxoplasma gondii IgM and CMV IgM. The results were calculated for each determination by referring the value to the cut-off value reading of the used kit.

The data presented as percentage, Z-test was used to test proportion from zero, $\quad \mathrm{p}<0.05$ was considered significant.

\section{Results}

Enzyme linked immunosorbent test (ELISA) revealed three cases of active toxoplasmosis and the remaining are negative results as seen in table 1 .

ELISA IgM test revealed 10 seropositive of CMV out of 90 serum samples as shown in table 1.

The infection with toxoplasmosis and CMV were compared with the time of sample collection as shown in table 2 .

The total and seropositive samples are distributed according to the donor residence as urban or rural donors as shown in table 3.

Table 1. Toxoplasma gondii and CMV IgM ELISA test results for the selected samples $(\mathrm{n}=90)$

\begin{tabular}{|c|c|c|c|c|}
\hline Test/ Group & Positive & Negative & Total & P value \\
\hline $\begin{array}{c}\text { Toxoplasma } \\
\text { gondii IgM }\end{array}$ & $3(3.4 \%)$ & $87(96.6 \%)$ & $90(100 \%)$ & NS* \\
\hline CMV IgM & $10(11.11 \%)$ & $80(88.88 \%)$ & $90(100 \%)$ & $<0.01$ \\
\hline
\end{tabular}

*NS: Not significant. 
Table 2. Time distribution of Toxoplasma gondii and CMV infection (months of collection)

\begin{tabular}{|l|c|c|c|}
\hline \multicolumn{1}{|c|}{ Infection/groups } & $\begin{array}{c}1^{\text {st }} \text { group } \mathrm{n}=30 \\
\text { (DEC.JAN) }\end{array}$ & $\begin{array}{c}2^{\text {nd }} \text { group } \mathrm{n}=30 \\
\text { (FEB- MAR) }\end{array}$ & $\begin{array}{c}3^{\text {rd }} \text { group } \mathrm{n}=30 \\
\text { (APR-MAY) }\end{array}$ \\
\hline CMV & 3 & 3 & 4 \\
\hline Toxoplasma gondii & 2 & 1 & 0 \\
\hline
\end{tabular}

Table 3. Urban- rural distribution of total and seropositive samples

\begin{tabular}{|l|l|l|l|}
\hline \multirow{2}{*}{\multicolumn{1}{c|}{ samples }} & \multicolumn{2}{|c|}{ locality } & \\
\cline { 2 - 4 } & urban & rural & Total \\
\hline Collected samples & $\mathrm{N}=56(62.2 \%)$ & $\mathrm{N}=34(37.7 \%)$ & $\mathrm{N}=90(100 \%)$ \\
\hline Toxoplasma gondii & $\mathrm{N}=2(67.7 \%)$ & $\mathrm{N}=1(33.3 \%)$ & $\mathrm{N}=3(3.4 \%)$ \\
\hline CMV & $\mathrm{N}=8(80 \%)$ & $\mathrm{N}=2(20 \%)$ & $\mathrm{N}=10(11.11 \%)$ \\
\hline
\end{tabular}

\section{Discussion}

Toxoplasma gondii parasite is able to parasitize peripheral blood leukocytes $^{25}$ as well as tissue leukocytes. Human studies demonstrate that there is parasitemia caused by Toxoplasma gondii in asymptomatic blood donors and in women who delivered congenitally infected infants ${ }^{15}$.

The risk of acquiring Toxoplasma gondii via blood transfusion was estimated by this study as about $3 \%$ of donated samples are able to transmit Toxoplasma gondii, and such result is in accordance with a study made by Sundar et.al ${ }^{27}$ in India which showed $3.6 \%$ were seropositive for Toxoplasma gondii $\operatorname{IgM}^{27}$, and with other study conducted in Saudi Arabia by Al-Harthi SA et $\mathrm{al}^{28}$ showed there were $5.6 \%$ seropositive for Toxoplasma gondii IgM, , in the other hand a study in Mexico by AlvaradoEsquivel et $a l^{12}$ revealed that there is about $1.9 \%$ of Toxoplasma gondii IgM seropositive in there locality which is relatively lower than the results of this study, such percent variance could be due to differences in climatic conditions, culinary habits and exposure to the sources of infection ${ }^{29}$, and also supported by Bobic et $\mathrm{al}^{30}$ and Logar et $\mathrm{al}^{31}$ who indicated a significant changes in infection rate by seasons and climate temperature.

The results of Cytomegalovirus IgM in this study is comparable to Henle et $a l^{32}$ who estimated that $5-10 \%$ of blood donors are CMV IgM seropositive, and also to a study conducted by Amarapa $\mathrm{P}$ et $a l^{33}$ in Thai who also estimate the CMV IgM 10.6\% and it is relatively much lower than a study conducted in Nigeria ${ }^{34}$ which showed $19.5 \%$ CMV IgM seropositive results among blood donors, while the results in this study is much higher than the results of a study conducted by Chaudhari S et al ${ }^{35}$ in India who revealed only $1.6 \%$ were 
CMV IgM seropositive, such variance could be due to seasonal changes especially humidity degree as explained by Chan VF et $\mathrm{al}^{36}$ and this is in consistence with results of this study which showed increment in CMV IgM level with rise in temperature and humidity.

The donated blood is given to patients with many acute conditions and the majority of them are immune compromised and they at a higher risk of acquiring infection with these microorganisms, and since both microbes can still be localized in leukocytes even if the donors are signs free, the risk of transmission still represents a biohazard problem.

In conclusion the risk of toxoplasmosis and CMV transmission represents $3 \%$ and $10 \%$ respectively of donated blood at the research period.

\section{References}

1. Hill DE, Chirukandoth S, Dubey J. Biology and epidemiology of Toxoplasma gondii in man and animals. Anim Health Res Rev 2005;6:41-61.

2. Montoya JG, Liesenfeld O. Toxoplasmosis. Lancet 2004;363:1965-76.

3. Brooks G, Butel J, Morse S. Jawetz, melnick \& adelberg's Medical microbiology. $22^{\text {nd }}$ ed. USA, McGraw-Hill; 2001. p.5824.

4. Toxoplasmosis: parasitic infections: Merck Manual Home Edition, sec 17/ch196r.html.

5. Kravetz JD, Federman DG. Toxoplasmosis in pregnancy. Am J Med 2005;118:212-6.

6. Walker M, Zunt JR. Parasitic central nervous system infections in immunocompromised hosts. Clin Infect Dis 2005;40:1005-15
7. Dubey JP. Toxoplasmosis - a waterborne zoonosis. Vet Parasitol. 2004;126:57-72.

8. Barsoum RS. Parasitic infections in transplant recipients. Nat Clin Pract Nephrol 2006; 2:490-503.

9. Figueroa Damian R. Risk of transmission of infectious diseases by transfusion. Ginecol Obstet Mex 1998; 66:277-83.

10. Wurzner R. Transplantationassociated infections. Verh Dtsch Ges Pathol 2004; 88:85-8.

11. Campbell AL, Goldberg CL, Magid MS, et al. First case of toxoplasmosis following small bowel transplantation and systematic review of tissueinvasive toxoplasmosis following non cardiac solid organ transplantation. Transplantation 2006;81:408-17.

12. Alvarado-Esquivel C, MercadoSuarez F, Rodriguez-Briones A. et al. Seroepidemiology of infection with Toxoplasma gondii in health blood donors of Durango, Mexico. BMC Infect Dis 2007;7:75.

13. Miller M, Arronson W, Remington J. Late parasitemia in asymptomatic acquired toxoplasmosis. Ann Int Med 1969;71:139.

14. Mandel GL, Bennett GE, Dolin R. Mandel, Doglas and Bnnett's. Principles and practice of infectious diseases. $4^{\text {th }} \mathrm{Ed}$. Churchill- Livingstone, 1995; 117,1351-64.

15. Pertal P, Hirschtick R, Phair J, et al. Risk of developing cytomegalovirus retinitis in persons infected with the human immunodeficiency virus. J Acquir Immune Defic Syndr Hum Retrovirol 1992;5:1069-74.

16. Knipe DM, Howley PM. Fields Virology. Philadelphia: Lippincott 2001. P.2675-706. 
17. Winn Washington Jr, Allen S, Janda W, et al. Koneman's color atlas and textbook of diagnostic microbiology. Lippincott Williams $\&$ Wilkins; $6^{\text {th }}$ ed. 2006. P. s113.

18. Turune J, Leinikke O, Saari M. Demonstration of intraocular synthesis of immunoglobulin $G$ Toxoplasma antibodies for specific diagnosis of toxoplasmic chorioretinitis by enzyme immunoassay. J Clin Microbiol 1983;17:988-92.

19. Lin M, Halbert P, O'Connor R. Standardized Quantitative enzymelinked immunoassay for antibodies to Toxoplasma gondii. $\mathrm{J}$ Clin Micobiol 1980;11:675-81.

20. Roller A, Bartlett A, Bidwell E. Enzyme immunoassay with Special Reference to ELISA Technique. J Clin Path 1987;31:507-20.

21. Voller, A, Bidwell E, Barlett A, et al. A Microplate Enzymeimmunoassay for Toxoplasma Antibodies. J Clin Path 1976;29:150-3.

22. Voler A, Bidwell JE, et al. Manual of clinical immunology. In: Rose, $\mathrm{N}$ and Friedman, $\mathrm{H}$ editors. Am Soc Microbiol 1985;506.

23. Cremer NE. Antibodies in serodiagnosis of viral infection. In Lennett EH editor laboratory diagnosis of viral infection. New York: Mercel Dekker, inc. 1985. P. 73.

24. Starr SE. Friedman HM. Human CMV. In: Lennette EH, Balows WJ, Hausler Jr, Shadomy HJ editors. Manual of Clinical Microbiolology $4^{\text {th }}$ ed.

American Society for Microbiology 1985. p771-91.

25. Huldt G. experimental toxoplasmosis. Effect of corticosteroids on rabbits with varying degrees of immunity. Acta Path Microbiol Scand 1966;68:604.
26. Siegal S, Lunde M, Gelderman A, et al. Transmission of toxoplasmosis by leukocytes transfusion blood. Blood 1971;37:388-94.

27. Sundar P, Mahadevan A, Jayshree $\mathrm{S}$, et al .Toxoplasma seroprevalence in healthy voluntary blood donors from urban Karnataka. Indian J Med Res 2007;126:50-5.

28. Al-Harthi SA, Jamjoom MB, Ghazi HO. Seroprevalence of Toxoplasma gondii among pregnant women in Makkah, Saudi Arabia. Umm Al-Qura Univ J Sci Med Eng 2006;18(2):217-27.

29. Al-Amari OM. Prevalence of antibodies to Toxoplasma gondii among blood donors in Abha, Asir Region, south-western Saudi Arabia. J Egypt Public Health Assoc 1994;69(1-2):77-88.

30. Bobić B, Klun I, Nikolić A, et al. Seasonal variations in human Toxoplasma infection in Serbia. Vector Borne Zoonotic Dis 2010;10(5):465-9.

31. Logar J, Oba B. S $\backsim$, Premru-Srsen T, Novak-Antolic Z. Seasonal variations in acute toxoplasmosis in pregnant women in Slovenia. Clin Microbiol Infect 2005;11(10):852-5.

32. Henle W, Henle G, Scriba M, et al. Antibody responses to the EpsteinBarr virus and Cytomegaloviruses after open-heart and other surgery. N Engl J Med 1970; 282:1068-74.

33. Amarapal P, Tantivanich S, Balachandra K. Prevalence of Cytomegalovirus in Thai blood donors by monoclonal staining of blood leukocytes. Southeast Asian J Trop Med Public Health 2001;32(1):148-53.

34. Akinbami AA, Akanmu AS, Adeyemo TA, et al. Cytomegalovirus antibodies among healthy blood donors at 
Lagos University Teaching

Hospital. S Afr Med J 2009; 99:528-30.

35. Chaudhari S, Bindra C. Seroprevalence of

Cytomegalovirus among Voluntary Blood Donors. MJAFI 2009; 65:252-4.
36. Chan VF, Soriano LR, Limson $\mathrm{BM}$, et al. Incidence and Seasonal Variation of Some Respiratory and Other Viral Infections Among Filipino infants and Children. Phil J Microbiol Infect Dis 1982;11(2):85-90. 